\begin{tabular}{c} 
Volume and Issues Obtainable at Center for Sustainability Research and Consultancy \\
Journal of Accounting and Finance in Emerging Economies \\
ISSN: 2519-0318 \& ISSN (E): 2518-8488 \\
Volume 7: Issue 4 December 2021 \\
CSRட \\
Journal homepage: www.publishing.globalcsrc.org/jafee \\
\hline
\end{tabular}

\title{
Islamic Banking Prospects, Challenges, and Criticism- A Systematic
}

\section{Literature Review}

\author{
Azam Anwar Khan, Lecturer DHA Suffa University, Pakistan \\ *Saqib Ghias, Senior Lecturer DHA Suffa University, Pakistan \\ Syed Irfan Hyder, Ziauddin University Hospital, Karachi, Pakistan
}

*Corresponding author's email: saqib.ghias313@gmail.com

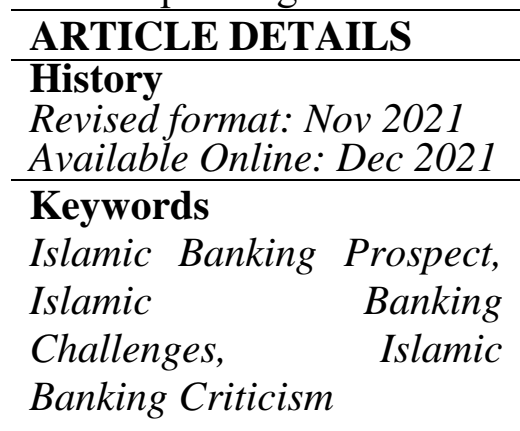

JEL Classification G20, G21

\begin{abstract}
Purpose: The article covers the prospects, challenges and criticism of Islamic Banking. There is still a confusion among people about the differences in Islamic and commercial banking. The implementation of Islamic banking is not as per the true spirit with which it was started.

Methodology/Approach: A systematic literature review was conducted and a thorough research was carried out by studying 2725 articles and finally qualifying thirty articles ( 30 articles) for the review

Findings: The results revealed that there is still a confusion among people regarding the difference between Islamic and Conventional banking. The Islamic banks should organize more awareness programs to improve the knowledge of people regarding Islamic banks. The social objectives of Islamic banks are not highlighted from their operations.

Implications/Originality/Value: This articles contributes to the literature by giving important insights regarding the Islamic Banking industry. The Islamic Banks can definitely improve by adopting the suggestions given in paper.
\end{abstract}

(C) 2021, The authors, under a Creative Commons AttributionNonCommercial 4.0

Recommended citation: Khan, A. A., Ghias, S. and Hyder, S. I. (2021). Islamic Banking Prospects, Challenges, and Criticism- A Systematic Literature Review. Journal of Accounting and Finance in Emerging Economies, 7(4), 921-930.

\section{Introduction}

The number of Islamic financial institutions is 300 in over 75 countries, mainly located in the Middle East and Southeast Asia. Islamic banking has gained acceptance in Europe, the USA, and Africa and is now present in every continent. Islamic bank's acceptance is very good and some western banks have also opened up the Islamic Banking window(Ezeh \& Nkamnebe, 2018). The transactions of Islamic banks in different Muslim countries like Iran, Sudan, and Malaysia provide evidence of Islamic banks offering a good banking solution. 
Islamic banking appeared in the twentieth century and has grown in the last 20 years. This success is associated with free capital flow and the responsiveness of Muslims to the consequences of interest-centered dealings in their religion. The move from the traditional banking system to the Islamic Banking system is demonstrated by a perception to shift from a mortgage-based financial system to a fairly built plan. Islamic bank assets were valued at more than US \$ 2tn in 2015, and the number of Islamic banks operating worldwide exceeded 775 numbers. Pakistan is also striving hard to promote Islamic banks and this can be seen in the growth of Islamic bank branches from 150 in 2007 to 2146 in 2016. (Majeed \& Zainab, 2018) Islamic Bank growth and financial progress were studied by taking data from 52 countries from 1990-2010. Results reveal that Islamic banking is connected with economic development. The key avenue of transmittal includes capital gathering and better financial addition, particularly improved connection to deposits. Islamic countries suffering from low growth must develop this banking sector by updating the judicial, controlling, and developing better infrastructure. Similarly Islamic banking adopted by non-muslim countries also helps them in the growth of their economies. (Imam \& Kpodar, 2016)

Islamic banking is an evolving invention in Nigeria; and has emerged as a new truth in the financial system of Nigeria (Ezeh \& Nkamnebe, 2018). The researchers recognized 12 independent variables namely provisional preference, congeniality, intricacy, believability, durability, vagueness, advertising effort, perception, customer pre-occupation, anticipated information worth, profit/ loss allocation, and religiousness as appropriate variables for the investigation of Islamic bank acceptance in Nigeria. Islamic banking is a contemporary and new product and is dissimilar from traditional banking, it is expected that upon implementation of the conceptual framework it will provide a very valuable understanding of the embracing behavior of Islamic bank customers in Nigeria.

Islamic banking advocates provision, financing, more authority, and rationality in every facet of society. During economic trouble, Islamic banking remains steadfast due to resource-backed and sustained resource financing in its goods (Ahmad, Farooq, \& Imran, 2021). There is a growing trend in the Islamic banking market and its market segment is growing. Islamic Banking as defined by the State Bank of Pakistan is banking done in conformity with Islamic directions. The primary purpose of the Islamic Banking system is to eradicate RIBA from society by presenting Islamic funding goods. The Shariah board is the consultative board in Islamic banks. Regardless of all the Islamic financing steps taken by the Islamic bank, many Islamic intellectuals argue that they do not pursue the actual vigor of Shariah, nor do they offer transaction-backed products.

Research shows that customers are ready to invest in profit and loss sharing products but the problem they face is a lack of knowledge on its operations. Islamic banks are reluctant to offer Musharika products due to increased danger and agency issues. Ultimately, Islamic banks are unable to implement Musharika financing. (Ahmad \& Imran, 2021)

\section{Significance}

This study will help students, researchers, academicians, bankers to understand the prospects, challenges, criticism, and opportunities that exist in the market for Islamic Banks. The study will help all these stakeholders to work towards the betterment of Islamic banking in uplifting the economy as a whole.

\section{Contribution}

The study will add to the current body of knowledge by giving answers to the following questions:

Q1. What are the opportunities or prospects that are available to Islamic banks?

Q.3. What are the challenges which are faced by Islamic banks the world over?

Q.4. What criticism is faced by Islamic banks? 


\section{Chapter 2 Methodology \\ Method}

The main purpose of this review is to consolidate, investigate, and generate literature available on Islamic Banking and Finance. The systematic review is mainly aimed at 1.) Describing the recognized researches; (ii) classify and categorize the notable researches according to their central plan and their technical means; (iii) carry a serious assessment on the process and (iv) to pull key inference for proposed investigation (Qureshi, Aleemi, \& Hyder, 2019)

\section{Sources of Information and Search Strategy}

A systematic literature search was conducted in the database, namely Crossref, Google Scholar. Harzinger publish and perish used to take out most of the articles from the best journals. Articles from Journals such as Elsevier, Springer, Taylor, and Francis, Research gate were selected. Search terms included the following terms 1) Islamic Banking Prospects 2.) Islamic Banking Challenges 3.) Islamic Banking Criticism.

\begin{tabular}{|c|c|c|c|}
\hline Search Terms & Construct & Scope & Population \\
\hline $\begin{array}{l}\text { Islamic Banking } \\
\text { Prospects, Islamic } \\
\text { Banking } \\
\text { Challenges, Islamic } \\
\text { Banking Criticism }\end{array}$ & Islamic Banking & $\begin{array}{l}\text { Islamic Banking and } \\
\text { Finance }\end{array}$ & $\begin{array}{l}\text { All Islamic } \\
\text { Banks } \\
\text { Worldwide }\end{array}$ \\
\hline
\end{tabular}

\section{Inclusion and Exclusion Criteria}

\section{Search Criteria}

Inclusion criteria of articles are given as under:

Research articles published in impact factor journals in the English language

Articles published on the subject of Islamic Banking growth prospects, Islamic Banking Challenges and Islamic Banking criticism all included in the scope of the study

Variables included in the study should be related to the topic or the problem and not to any other topic or problem

Articles related to Islamic Banks were only included and articles related to conventional banks were not included

Exclusion criteria of articles are given below:

Articles not accessible were not included in the study

Articles published in a language other than English were not included

Conference proceedings

M.Phil and Ph.D. level thesis

\section{Screening}

Articles were screened based on inclusion criteria. Initially, the abstracts and titles were reviewed and articles selected. Some of the articles which came up during article searches were not related but were evaluated separately to see if they can be included.

\section{Quality Review}

Selected studies were further polished through a quality review instrument known as the "Mixed Methods Appraisal Tool (MMAT)"

\section{Results}

A thorough search was carried out by following the search criteria as given in the search strategy. Total records selected included 2725 research articles. By following the search criteria 225 articles were found eligible. These 225 articles were further screened and finally, 30 articles were selected for the systematic review. Below is a Prisma diagram showing the screening of articles. 


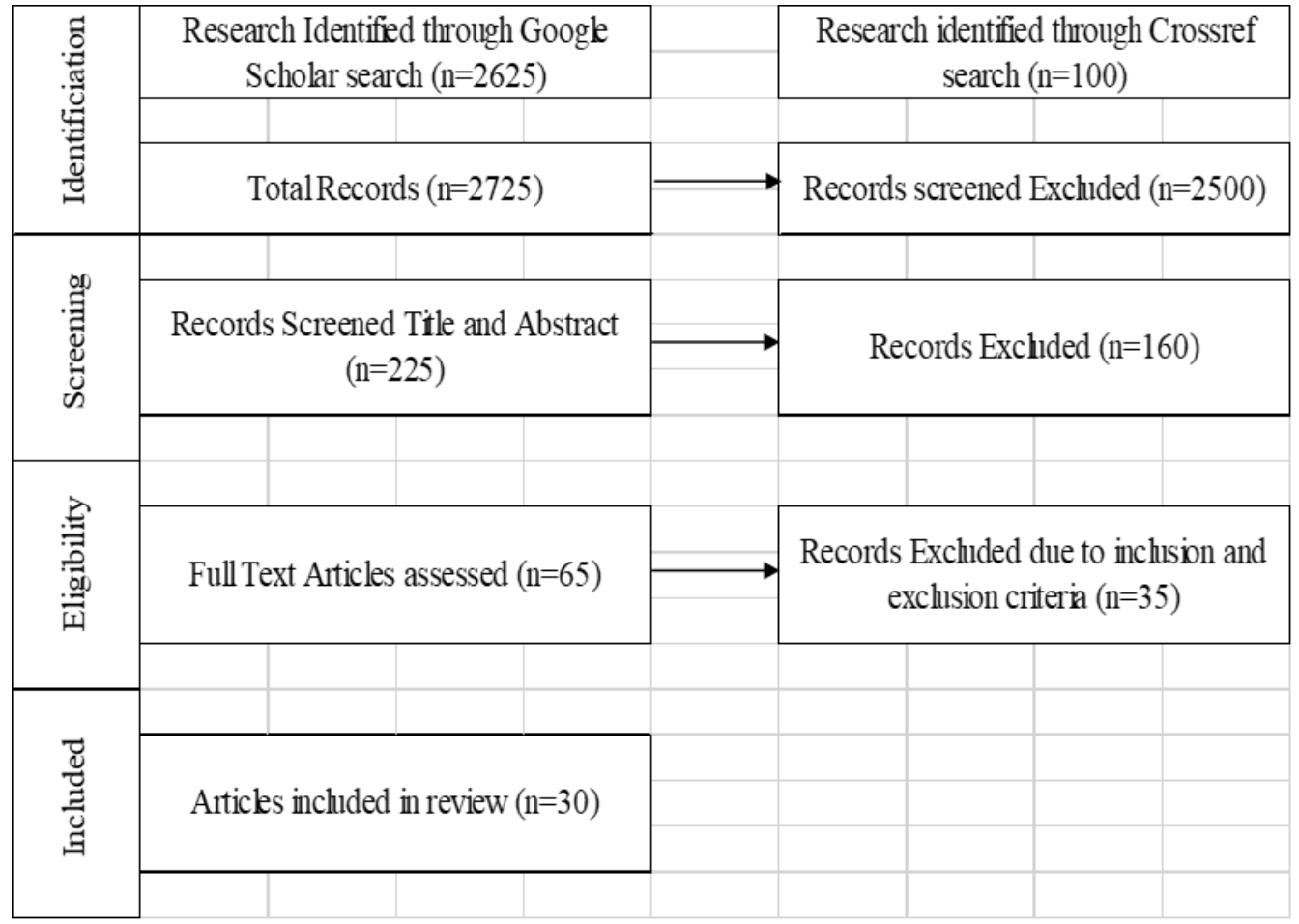

\section{Classification of Prospects, Challenges, Opportunities, and Criticism of Islamic Banking Prospects of Islamic Banking}

Islamic Banking awareness programs will create interest among the people. Most people due to unawareness are unable to understand the benefits of Islamic banking. It is therefore recommended that Islamic banks must launch awareness campaigns to educate people and it will help them in attracting more and more customers. (Blackwell et al, 2006; Dabor Aggreh, 2018; Shabbir \& Rahman, 2019). There is a need for Islamic banking in Non-Muslim countries. Many banks are ready to shift to Islamic Banking due to zero interest (Ahmed, 2008.; Dabor \& Aggreh, 2018). Islamic banks should arrange some facilities for the disadvantaged and neglected people as this will improve their customer base and also provide chances for the economy to grow (Shaikh, 2018; Shaikh et al., 2017). Islamic banks should try to expand in OIC countries as the percentage of account holders in these countries is very low and most of the people in these countries are disadvantaged. By providing soft loans to such a segment of society will allow Islamic banks to contribute to the development of an economy. Islamic Banking can help in the reduction of poverty by financing poor people through special funds. This special advantage can be the source of attraction for many governments who want to eradicate poverty from their system. (Dabor \& Aggreh, 2018; Wajdi Dusuki, 2008).

Ezeh \& Nkamnebe, (2019) investigated the chances of Islamic Banking in the south of Nigeria where the Non-Muslim population prevails. The decision of the Central Bank of Nigeria to accept the opening of the Islamic Banking operation was acknowledged by many with dubiousness. The Non-Muslims thought that Islamic Banking would never benefit them as it has aspects of Sharia in it. Some aspects of Islamic banks were proficient among Jews and Christians and advanced supported by socialist and financial experts. Religion set aside, communists denounced interest, as it strengthens a sponging survival. Interest has a very adverse influence on society. The author after a thorough literature review has made a structure for this study. The plan includes the following variables Information on Islamic Banking, Comparative benefit of Islamic Banking, prospective client religious affiliation, and views of Islamic banks. 


\section{Information on Islamic Banking}

Research suggests (Blackwell et al, 2006; Dabor \& Aggreh, 2018; Shabbir \& Rahman, 2019) that the buying commitment is dependent on the prospective customer's knowledge about the particular product. There is a lack of awareness regarding Islamic banking products and it is necessary to launch awareness programs for people to adopt Islamic banks. Customer consciousness regarding Islamic banks in Nigeria has received little consideration.

\section{Comparative benefit of Islamic banks}

The study contemplated comparative benefit in the situation of values of Islamic banking. How the Non-Muslims recognize Islamic banking will decide the outlook of Islamic banking.

\section{Religion}

Researchers have established that Muslims value religious reasons more for the adoption of Islamic banks. Profitability is again a very important point for Islamic banking adoption apart from Religion. As the current population is of non-muslims therefore the researchers have investigated whether religion influences the acceptance of Islamic Banking.

Islamic banks must highlight the bright aspects of Islamic Banking to non-Muslim customers. More customers would be attracted to Islamic banks if it launches a useful marketing promotion. The promotion campaigns will help in growing the consciousness of Non-Muslim customers ultimately increasing the customer base ((Ezeh \& Nkamnebe, 2019).

Nigerian customers are attracted to conventional banks as they fulfill their personal needs like asset purchases, disbursement of school fees for their children, and charging high interest rates. The study recommends training Islamic banking personnel, launching marketing programs for awareness among the masses, and starting products that offer loans to consumers to meet their necessities. (Dabor \& Aggreh, 2018)

\begin{tabular}{|c|c|}
\hline \multicolumn{2}{|c|}{ Islamic Banking Prospects: Key takeaways } \\
\hline Prospects of Islamic Banking & Solution \\
\hline Lack of Awareness ${ }^{1}$ & Awareness Programs \\
\hline Need of Muslims living overseas ${ }^{2}$ & Expand branches to other countries \\
\hline Utilize the OIC Market $^{3}$ & Expand in OIC countries \\
\hline Agriculture and Underprivileged areas ${ }^{4}$ & Finance agriculture and underprivileged areas \\
\hline Social and Monetary problems ${ }^{5}$ & Awareness that IB will ease this problem \\
\hline \multicolumn{2}{|l|}{ References: } \\
\hline 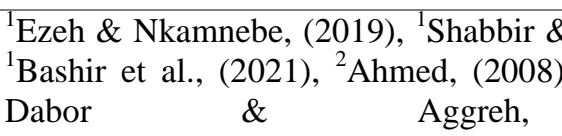 & $\begin{array}{l}\text { Dabor \& Aggreh, }(2018),{ }^{1} \text { Charles, }(2021), \\
\text { 017), }{ }^{4} \text { Shaikh, (2018), }{ }^{4} \text { Hassan, }(2020), \\
{ }^{5} \text { WajdiDusuki,(2008), }{ }^{5} \text { Siddiqi, }(2006)\end{array}$ \\
\hline
\end{tabular}

\section{Challenges facing Islamic Banking}

Islamic banks face challenges in western countries due to their regulatory setup which supports traditional banks and not Islamic banks. In some Muslim countries, the Government is not very cooperative in establishing Islamic Banks. (Ahmed, 2008; Meisamy \& Gholipour, 2020). The Shariah supervisory board in Islamic banks is not performing according to shariah standards as these Islamic banks are not contributing to poverty alleviation. In other Muslim countries, the Shariah supervisory board does not exist at all.(Majeed \& Zainab, 2017; Meisamy \& Gholipour, 2020; Yanīkkaya \& Pabuçcu, 2017). Most of the Islamic Banking transactions are focused on Murabaha instead of PLS-based products. The main theme behind Islamic banking is that it encourages PLS-based funding but in actual the balance sheet of Islamic Banking is filled with Murabaha and Ijara based financing. The participatory form of financing is possible only when 
there is a true Islamic state where every institution approves and works for the achievement of common goals and objectives. If the PLS-based financing is to be promoted then it is necessary to bring improvements in the system otherwise non-participatory forms of financing will dominate Islamic banking. (Miah \& Suzuki, 2020; Nouman et al., 2018). Islamic banking products are costlier when compared to traditional banks. The average cost of financing is more when compared with traditional banks. Islamic finance is associated with distinctive risks and costs, therefore, requiring the bank to maintain more funds to cover the risks hence making the finance more expensive

The Islamic banking system was not allowed to operationalize as the government deemed it cannot operate in India. Again in 2014 Shariah mutual fund launched was stopped by the Government as one of the ministers shared his concern that Islamic banking will be destructive for the Indian economy. The minister also said that it might lead to the transfer of doubtful funds to India through Islamic Banks(Charles, 2021).

The author further suggests the following points for the promotion of Islamic Banking in India.

1.) Awareness seminars for increasing the knowledge level of people

2.) Make people aware that Islamic banking will help alleviate social and fiscal problems

3.) Islamic banking offers a window of opportunity for needy people not provided by traditional banks

4.) Islamic banks must provide exceptional customer services when with conventional banks so the acquisition and maintenance of new customers is easy

The financing principles of Islam do not allow interest and include a large number of people and companies in the financial system. Islamic ideology says that the entire fortune belongs to Allah and man/ woman is only the guardian of it. The research suggests that the commencement of Islamic finance in India will generate more financial additions. The study demonstrates that IFS (Islamic Financial System) is selected by individuals who have low income, not a very good occupation. Consequently, the IFS should be promoted in India to generate more financial insertion (T. Ahmad et al., 2021).Wasrsam (2009) defines financial addition as 'the proportion of residents or persons and companies using the monetary services". According to the world bank (2013), monetary additional can considerably add to poverty reduction and increase the rate of occupation and affluence.

The conduct of Islamic banks is determined by calculable measures towards the development of a wide-ranging financial system. The outcome of the investigation shows that there is a difference between claim and reality. Islamic banks are more focused on the commercial area and privileged class individuals and charging high financing costs. There might be a need for finance for the establishment of small businesses, health and education purposes but Islamic banks do not have anything to offer from their available product schemes. Islamic banks are mostly operating in big urban centers and Islamic banking products are costlier than conventional banking products (Shaikh, 2018). The paper suggests that for rapid growth Islamic banks should take the following steps:

1.) Concentrate on developing branch networks in rural areas

2.) More importance should be given to agriculture, small and medium enterprises

3.) The bank must also offer inexpensive financial products for quicker adoption among the masses

Meisamy \& Gholipour, (2020) investigate the threats that are faced by Islamic banking in Iran. The main challenges are listed below:

1.) The Executive approach to Islamic Banking

2.) Absence of rivalry

3.) Not reviewing the law (RFBA)

4.) Absence of Shariah guidance

5.) Absence of bookkeeping and verification code 
On Bank productivity, some find Islamic banks are well-organized than traditional banks whereas others do not find any variations between these two banks. Second small Islamic banks are more established and can lessen the risk well. Third Islamic banks are backed by excellent assets and the chances of fiasco are lesser as compared to commercial banks. Fourth, Islamic banks are more prone to aid SMEs (Narayan \& Phan, 2019)

Investigation on moral problems reveals these important points. 1.) Moral problems and CSR objectives are not followed by many Islamic financial institutions. 2.) There is varied proof of the association between ethical issues of bank/ organizational conduct. This area of Islamic finance needs more research to come to some agreement.

Certain challenges were identified in the (Narayan \& Phan, 2019) study. These are 1.) Islamic finance should be considered as a distinct entity and separate studies should be conducted on it. This is will develop the field of Islamic finance. Most research on Islamic finance is conducted in a comparative sense with traditional finance. 2.) The availability of superior and rare data related to Islamic finance is very important. It will help in solving exclusive Islamic finance-related study queries. 3.) The focus should be on researching comparatively less investigated topics like asset valuing, and bond marketplaces. With the availability of new data research on these topics will be done more easily. 4.) Absence of research on commercial finance linked subjects in Islamic finance. There is a dearth of knowledge on such topics as the basis of capital organization, swiftness of change to force, and the factors which decide leverage. 5.) Determining the vigor of the experimental finds is also an obstacle. The researcher believes that the trend of empirical research is continuing and with time new techniques will appear which will provide main findings and inferences with little hesitation.

Islamic Banking Challenges worldwide: Key Takeaways

\begin{tabular}{|c|c|}
\hline Challenges & $\begin{array}{l}\text { Solution } \\
\mathrm{S}\end{array}$ \\
\hline Lack of co-operation by non-Muslim Governments ${ }^{1}$ & Awareness seminars of Islamic Banking benefits \\
\hline Shariah Supervisory Board not up to mark ${ }^{2}$ & Shariah literate people to be on board \\
\hline More focus on Murabaha contract ${ }^{3}$ & More equity-based contracts to be promoted \\
\hline Islamic banks more expensive ${ }^{4}$ & Must offer competitive products \\
\hline References: & \\
\hline
\end{tabular}

\section{Islamic Banking Criticism}

The basic foundation of Islamic banking is on the Profit and Loss sharing system. This system is not being followed by Islamic banks (Chong \& Liu, 2009; T. Khan, 2018; Majeed \& Zainab, 2017). Islamic banking is more focused on the non-participatory form of financings like Murabaha and Ijara (Dar \& Presley, 2000; F. Khan, 2010; Nouman et al., 2018) however Islam focuses more on the participatory form of financing like the Modarba and Musharika. Another criticism of Islamic banking is that the products are debt-based (Ali \& Hussain, 2016; Azmat et al., 2015; Miah \& Suzuki, 2020). Islamic banks must introduce profit and loss sharing products to overcome this criticism. Islamic banks are not influencing the less privileged sector of society (Alkhan \& Hassan, 2021; Hamidi et al., 2019; Shaikh, 2018). Islamic banks must cater to the less privileged sector by introducing CSR, and providing loans to the less privileged section of society. Many of the scholars do not have a consensus on the shariah compliance of Islamic banking products (Ahmad \& Imran, 2021; Butt et al., 2011; Saputro et al., 2018). Islamic banks 
must try and bring out products that are more Shariah-compliant and have the consensus of all religious scholars. Another criticism of Islamic banking is that it is considered as just equivalent to conventional banks and people think of it as just name change and regard it as being unIslamic (Majeed \& Zainab, 2018; Saputro et al., 2018; Shabbir \& Rahman, 2019). The Islamic banks must launch an awareness campaign among the masses to correct this misconception and make people aware of what steps Islamic Banks are taking to practically implement Islamic banking in society.

Scholars' opinion is divided on the Islamic banking role of achieving societal goals. Few think that Islamic banks are business enterprises and should be allowed to function freely if they are complying with Shariah laws. On the contrary, many scholars think that the Islamic bank's purpose is to back and inspire a fiscal system that helps in the creation of an unprejudiced, impartial and stable society. Another author (Al-Zuhayli, 2003, p.250) indicated "the chief objective of Islamic Bank is not earning profit but the authorization of social objectives of socioeconomic growth and reduction of underdevelopment."

The outcome of the research specifies that the societal consequences of Islamic Banking are truncated. Research participants view Islamic banks as not doing enough to meet their social responsibility. Secondly, participants agree with the view of merging CSR and the ZIS-Waqf system $(52.9 \%)$ or expanding the capacity of CSR $(25.1 \%)$. Thirdly the combination of the ZISWaqf system might be possible hypothetically but is not possible practically as many lawful issues may arise. Participants think that ISB must operate in areas of less privileged people so they can benefit from it. The ISB must develop a transparent system to monitor the financing of both lucrative and virtuous projects. ISB's priority should be to support SME's and the farming sector.

Islamic Banking has been widely criticized for not following Shariah rules. Islamic Banks have become very popular worldwide in both Muslim and Non-Muslim countries. The value of assets of Islamic banks stood at US \$ 2TN in 2015 and the number of Islamic banks is more than 775. Pakistan is also among the countries which are struggling hard to support Islamic banks. There has been a rapid growth in the number of Islamic banks in Pakistan from 150 in 2007 to 2146 in 2016. (Majeed \& Zainab, 2018)

Islamic Banking Criticism: Key Takeaways

\begin{tabular}{|c|c|}
\hline Criticism & Solution \\
\hline PLS system not implemented $^{1}$ & PLS system to be implemented \\
\hline Non-participatory form of financing ${ }^{2}$ & Mudarba and Musharika to be introduced \\
\hline Debt-based products ${ }^{3}$ & Equity-based products to be introduced \\
\hline No impact on less privileged people ${ }^{4}$ & Introduction of CSR, ZIS-Waqf system \\
\hline Products are not Shariah compliant $^{5}$ & Shariah-compliant products to be introduced \\
\hline Islamic Banking being considered un-Islamic $^{6}$ & Awareness campaign among masses \\
\hline \multicolumn{2}{|l|}{ References } \\
\hline \multicolumn{2}{|c|}{ 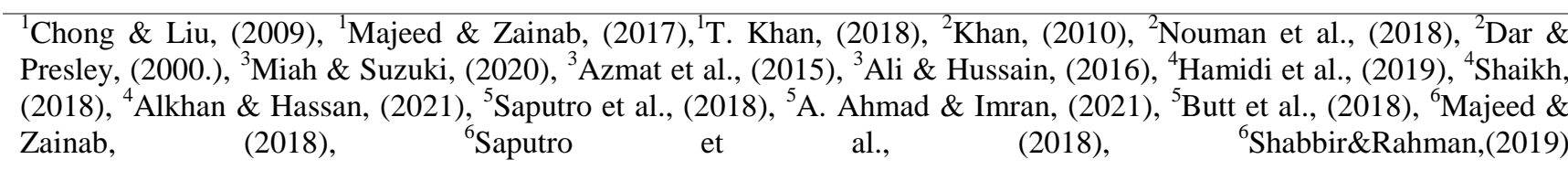 } \\
\hline
\end{tabular}




\section{Conclusion}

The findings of the systematic review suggest the following things:

People have not been able to distinguish between Islamic Banks and commercial banks because Islamic banks have not been able to highlight their social objectives from their operation and function. Future research in this area would suggest a framework where the social objectives of Islamic Banking are highlighted and a clear differentiation is made between commercial and Islamic banks. The religious scholars had proposed a framework for Islamic banks where social objectives were also highlighted before the launch of Islamic Banks.

\section{Gap Identification and Future Research}

1.) The social responsibility of Islamic banking is an area that has not been researched. It is recommended that this area should be covered highlighting the achievements or shortcomings of Islamic Banks in this area.

2.) Islamic bank's responsibility is to promote equal opportunity for everyone in society. People who do not have capital but a good idea can be supported by Islamic banks on Profit and loss sharing system. Future research should be done on how Islamic banks have contributed in this area and how it can be executed for the betterment of society

3.) Islamic banks can help reduce poverty. This is an area that needs to be investigated and can highlight Islamic banks existing contribution whereas its plans for how to achieve it need to be highlighted.

4.) Future research can study the circumstances that can promote Musharika and Mudarba financing in Islamic Banks

5.) Future studies can also concentrate on what mediums should be adopted to make people aware of Islamic banks.

6.) Future research can also study how the Shariah Advisory Board helps in the functioning of the Islamic Bank. It will help masses and practitioners understand the importance of the Shariah Advisory board in the functioning of Islamic banks.

7.) Future research can also concentrate on the points which can bring a consensus among all Shariah scholars regarding the acceptability of Islamic banking products as per Shariah guidelines.

\section{References}

Ahmad, A., \& Imran, M. (2021). Islamic Banking Products: A Comparative Study of the Perception of Bankers \& Scholars.

Ahmed, W. (2008). "Islamic Banking in the United Kingdom: Opportunities and Challenges " Waseem Ahmad K 0540931 Kingston Business School, London. 1-111.

Ali, M. A., \& Hussain, T. (2016). EQUITY-BASED ISLAMIC FINANCE: A PRODUCT DEVELOPMENT PERSPECTIVE. 1(1), 119-127.

Alkhan, A. M., \& Hassan, M. K. (2021). Does Islamic microfinance serve maqāsid al-shari'a? Borsa Istanbul Review, 21(1), 57-68. https://doi.org/10.1016/j.bir.2020.07.002

Azmat, S., Skully, M., \& Brown, K. (2015). Can Islamic Banks ever become Islamic? PacificBasin Finance Journal. https://doi.org/10.1016/j.pacfin.2015.03.001

Butt, I., Saleem, N., Ahmed, H., Altaf, M., Jaffer, K., \& Mahmood, J. (2011). Barriers to adoption of Islamic banking in Pakistan. Journal of Islamic Marketing, 2(3), 259-273. https://doi.org/10.1108/17590831111164787

Charles, G. (2021). " A Study on the Challenges and Opportunity of Islamic Finance in India ." " A Study on the Challenges and Opportunity of Islamic Finance in India ." January, 0-20.

Chong, B. S., \& Liu, M. H. (2009). Islamic banking: Interest-free or interest-based? Pacific Basin Finance Journal, 17(1), 125-144. https://doi.org/10.1016/j.pacfin.2007.12.003

Dabor, A. O., \& Aggreh, M. (2018). Islamic Banking in Nigeria: Prospects and Challenges Islamic Banking in Nigeria: Prospects and Challenges. September 2017. 
https://doi.org/10.23918/ijsses.v4i1p120

Dar, H. A., \& Presley, J. R. (2000). Lack of Profit Loss Sharing in Islamic Banking: Management and Control Imbalances. 00.

Ezeh, P. C., \& Nkamnebe, A. D. (2018). A conceptual framework for the adoption of Islamic banking in a pluralistic-secular nation: Nigerian perspective. Journal of Islamic Marketing, 9(4), 951-964. https://doi.org/10.1108/JIMA-03-2017-0022

Ezeh, P. C., \& Nkamnebe, A. D. (2019). The prospects of Islamic banking in Southeast of Nigeria. Journal of Islamic Marketing, 11(1), 251-267. https://doi.org/10.1108/JIMA-032016-0023

Hamidi, M. L., Worthington, A., West, T., \& Ismal, R. (2019). the Prospects for Islamic Social Banking in Indonesia. Journal of Islamic Monetary Economics and Finance, 5(2), 237-262. https://doi.org/10.21098/jimf.v5i2.1062

Imam, P., \& Kpodar, K. (2016). Islamic banking: Good for growth? Economic Modelling, 59, 387-401. https://doi.org/10.1016/j.econmod.2016.08.004

Khan, F. (2010). Journal of Economic Behavior \& Organization How 'Islamic ' is Islamic Banking ? 76, 805-820. https://doi.org/10.1016/j.jebo.2010.09.015

Khan, T. (2018). DEMAND FOR AND SUPPLY OF MARK-UP AND PLS FUNDS IN ISLAMIC BANKING : SOME ALTERNATIVE EXPLANATIONS.

Majeed, M. T., \& Zainab, A. (2017). How Islamic is Islamic banking in Pakistan? International Journal of Islamic and Middle Eastern Finance and Management, 10(4), 470-483. https://doi.org/10.1108/IMEFM-03-2017-0083

Majeed, M. T., \& Zainab, A. (2018). Sharia'h practice at Islamic banks in Pakistan. Journal of Islamic Accounting and Business Research, 9(3), 274-289. https://doi.org/10.1108/JIABR03-2015-0011

Meisamy, H., \& Gholipour, H. (2020). Challenges Facing Islamic Banking in Iran: Evaluation and Policy Implications. Journal of Islamic Monetary Economics and Finance, 6(3), 621640. https://doi.org/10.21098/jimf.v6i3.1241

Miah, M. D., \& Suzuki, Y. (2020). Murabaha syndrome of Islamic banks: a paradox or product of the system? Journal of Islamic Accounting and Business Research, 11(7), 1363-1378. https://doi.org/10.1108/JIABR-05-2018-0067

Narayan, P. K., \& Phan, D. H. B. (2019). A survey of Islamic banking and finance literature: Issues, challenges and future directions. Pacific Basin Finance Journal, 53, 484-496. https://doi.org/10.1016/j.pacfin.2017.06.006

Nouman, M., Ullah, K., \& Gul, S. (2018). Why Islamic Banks Tend to Avoid Participatory Financing? A Demand, Regulation, and Uncertainty Framework. 10(1), 1-32.

Saputro, A. D., Rois, A. K., Bazi, U. Al, Ponorogo, U. M., \& Ponorogo, I. (2018). Heart Half Implementation Sharia Banking In Indonesia. 3(2), 127-138.

Shabbir, M. S., \& Rahman, A. (2019). Layers of misconceptions about Islamic banking Are Islamic banks threats, challenges and. https://doi.org/10.1108/JIMA-02-2018-0026

Shaikh, S. A. (2018). Role of Islamic banking in financial inclusiveness in Pakistan : promise , performance and prospects. 9(1), 88-102.

Shaikh, S. A., Ismail, M. A., Hakimi, M., Sha, M., \& Ismail, A. G. (2017). Role of Islamic Banking in Financial Inclusion: Prospects and Performance. 33-49. https://doi.org/10.1007/978-3-319-45910-3

Wajdi Dusuki, A. (2008). Banking for the poor: The role of Islamic banking in microfinance initiatives. Humanomics, 24(1), 49-66. https://doi.org/10.1108/08288660810851469

Yanīkkaya, H., \& Pabuçcu, Y. U. (2017). Causes and solutions for the stagnation of Islamic banking in Turkey. ISRA International Journal of Islamic Finance, 9(1), 43-61. https://doi.org/10.1108/IJIF-07-2017-005. 